\title{
Appendiceal Diverticular Disease: A 10-year Retrospective Study of Cases from Tertiary Hospitals in Western Australia
}

\author{
Pei Yinn Toh*, Simon Parys, Yuki Watanabe \\ Sir Charles Gairdner Hospital, Perth, Western Australia
}

*Corresponding author:

Pei Yinn Toh, MD

Sir Charles Gairdner Hospital

Perth, Western Australia

E-mail: peiyinn.toh@gmail.com

\section{Abbreviations:}

ADD - appendiceal diverticular disease; AA - acute appendicitis.

\author{
Rezumat \\ Boala diverticulară apendiceală: un studiu retrospectiv de 10 ani \\ a cazurilor din spitale terțiare din Australia de Vest
}

Introducere:Boala diverticulară apendicială (BDA) este de obicei diagnosticată histologic. Lucrarea noastră îşi propune să investigheze implicațiile BDA în comparație cu apendicita acută (AA). Metode: Am efectuat o colecție de date retrospective a pacienților care au suferit o apendicectomie în trei spitale terțiare din Australia de Vest în perioada 2009-2019, şi a inclus pacienți cu diagnostice histopatologice de BDA şi AA.

Rezultate: Au fost incluşi treizeci şi şapte de pacienți cu BDA şi patruzeci cu AA. Vârsta medie în grupul BDA a fost semnificativ mai mare $(\mathrm{p}<0,001)$ la 50,1 comparativ cu grupul AA $(37,3)$. Numărul mediu de celule albe (WCC) din grupul BDA a fost mai mic decât în grupul AA ( $11 \times 10^{9} / \mathrm{L}$ vs. $\left.13,3 \times 10^{9} / \mathrm{L}, \mathrm{p}<0,001\right)$, în timp ce nivelul proteinei C-Reactive (CRP) a fost mai mare, deşi nu statistic semnificativ. Grupul BDA a prezentat un risc mai mare de intervenție chirurgicală majoră $(p<0.05)$ şi complicații, cum ar fi perforația apendiceului şi masa apendiceală $(\mathrm{p}<0.05)$. Colonoscopia postoperatorie a demonstrat, de asemenea, o incidență mai mare de polipi la pacienții cu BDA (19\% față de $2,5 \%, \mathrm{p}<0,001)$.

Concluzie:BDA se prezintă frecvent cu caracteristici clinice imperceptibile, în compara $\square$ ie cu AA. Studiul nostru demonstrează că BDA este asociat cu rate mai mari de perforație apendiceală, polipi şi malignitate. Recomandăm ca pacienților cu BDA să fie îndruma $\square$ i spre efectuarea unei colonoscopii post-operatorii pentru a exclude malignitatea.

Cuvinte cheie: diverticul apendicel, apendicită acută, diverticulită 


\section{Abstract}

Background:Appendiceal diverticular disease (ADD) is typically a histological diagnosis. Our paper aims to investigate the implications of ADD compared to acute appendicitis (AA).

Methods: We conducted a retrospective data collection of patients who had undergone an appendicectomy in three tertiary hospitals across Western Australia between 2009-2019 and included patients with histopathological diagnoses of $\mathrm{ADD}$ and AA.

Results: Thirty-seven patients with ADD and forty with AA were included. The mean age in the ADD group was significantly older $(\mathrm{p}<0.001)$ at 50.1 compared to the AA group (37.3). The mean white cell count (WCC) in the ADD group was lower than the AA group $\left(11 \times 10^{9} / \mathrm{L} \mathrm{vs.} 13.3 \times 10^{9} / \mathrm{L}\right.$, $\mathrm{p}<0.001$ ), whereas the C-Reactive Protein (CRP) level was greater, although not statistically significant. The ADD group had a greater risk of major surgery $(p<0.05)$ and complications such as appendiceal perforation and appendiceal mass $(p<0.05)$. Post-operative colonoscopy also demonstrated a higher incidence of polyps in patients with $\mathrm{ADD}$ (19\% vs. $2.5 \%, \mathrm{p}<0.001)$.

Conclusion: ADD frequently presents with clinical features indiscernible from AA. Our study demonstrates that ADD is associated with higher rates of appendiceal perforation, polyps and malignancy. We recommend that patients with $\mathrm{ADD}$ be advised to have a colonoscopy post-operatively to rule out underlying malignancy.

Key words: appendiceal diverticulum, acute appendicitis, diverticulitis

\section{Introduction}

Appendiceal diverticular disease (ADD) is an uncommon entity that is not typically recognized clinically or even intra-operatively due to it frequently mimicking the presentation of acute appendicitis (AA). Following its first description in literature by pathologist Kelynack in 1893, ADD has since been further investigated and classified into congenital and acquired types $(1,2)$. The congenital form of ADD is associated with genetic mutations such as trisomy 13 and 15 and involves all layers of the muscularis propria, as opposed to the more prevalent acquired subtype of ADD, which is defined as herniation of the appendiceal mucosa through the muscularis mucosa layer at points of low resistance at the vascular hiatus $(3,4)$.

Its incidence has been described to range between $0.004-2.1 \%$ of appendicectomy histology sections and $0.2-1.89 \%$ of autopsy specimens (5). Despite ADD being a lesser known diagnosis with little attention paid to the clinical implications, this condition is not indolent with studies demonstrating an association with a higher risk of perforation and neoplasms, such as primary appendiceal carcinoma, neuroendocrine tumors and mucinous adenomas $(6,7,8)$.

With the difficulties encountered in diagnosing ADD pre-operatively either clinically, via imaging modalities or intra-operatively, more studies are required to raise awareness amongst clinicians of this diagnosis. In our retrospective study, we analyzed the patient demographics, biochemical results, imaging and histopathology in patients diagnosed with ADD and compared data in this group with patients who were diagnosed with AA to investigate the differences and potential clinical implications of this condition.

\section{Material and Method}

The combined pathology department database of three major tertiary hospitals was searched for consecutive cases of appendiceal diverticula over a ten-year period (2009-2019). The pathology records were then reviewed to assess if they met inclusion and exclusion criteria. Inclusion criteria was set as all patients aged over 15 with pathologically confirmed appendiceal diverticulum regardless of 
inflammation status. Exclusion criteria were children aged under 15 years and any cases where the appendiceal diverticulum was not confirmed on pathology. Individual patient records were then reviewed by the authors. Data collected included patient demographics, biochemical results on presentation and pathological findings including the subtype of diverticula. In addition, patient management and operative records were reviewed for the type of operation, operative findings and if a diverticulum was suspected. Length of stay data and follow-up data including colonoscopy results and presence of malignancy was also collected. This formed the appendiceal diverticula group (ADD). To allow for comparison a similar number of pathologically confirmed acute appendicitis patients were identified. These were consecutive patients, aged greater than 15, from the same hospitals over an approximately three-month period and formed the control acute appendicitis (AA) group. The data was collected into Microsoft Excel (Redmond, USA) and statistical analysis was performed with ANOVA and T-Test to compare the ADD group to the AA group. Statistical significance was defined as $p<0.05$. The study was registered with the appropriate institutional quality improvement body and provided with a waiver of consent.

\section{Results}

A total of 43 patients were originally identified during the study period with 37 meeting the inclusion and exclusion criteria forming the ADD group. To allow for comparison, 40 control patients were recruited to the AA group. The age of the ADD group was significantly higher (mean 50.1, range 15-90) compared to the AA group (mean 37.3, range 16-83) $\mathrm{p}<0.01$. There was a male predominance $(62.1 \%$ male vs $37.9 \%$ female) in the ADD group compared to the AA group ( $52 \%$ vs $48 \%$ ). The number diagnosed per year varied between zero to nine with an average of 3.4 diagnosis per year.

Biochemically, the presentation white cell count (WCC) was significantly lower in the ADD group (mean 11.1 range 5.2-17.2) compared to the AA group (mean 13.3, range 5.8-23.1) $\mathrm{p}<0.01$. The C-Reactive Protein (CRP) although higher in the ADD group (mean 91.9, range $1-380$ vs mean 68.1 , range $1-410$ ) was not statistically significant $(\mathrm{p}>0.05)$.

The use of imaging was comparable between the two groups with twenty patients having computerised tomography (CT), four ultrasound scan (USS) and thirteen having no scans in the ADD group versus twenty-one patients with CT, eight with USS, and eleven had no scans in the AA group. The use of imaging did not result in any diagnosis of appendiceal diverticula with the imaging reporting a diagnosis of uncomplicated appendicitis (14 patients), appendicitis with abscess, collection or phlegmon (6 patients) or perforated appendicitis (4 patients). The basic demographic and investigation results are summarised in Table 1.

Table 1. Basic demographics

\begin{tabular}{lccc}
\hline & $\begin{array}{c}\text { Appendiceal Diverticular Disease } \\
\text { (ADD) }\end{array}$ & $\begin{array}{c}\text { Acute Appendicitis control group } \\
\text { (AA) }\end{array}$ & p value \\
\hline Number & 37 & 40 & \\
\hline Male & $23(62 \%)$ & $21(52 \%)$ & \\
\hline Female & $14(38 \%)$ & $19(48 \%)$ & \\
\hline Age & $50.1(15-90)$ & $37.2(16-83)$ & $p<0.001$ \\
\hline White cell count (WCC) & $11(5.2-17.2)$ & $13.3(5.8-23.1)$ & $p<0.001$ \\
\hline C-reactive protein (CRP) & $91(1-380)$ & $68(1-410)$ & \\
\hline Computed tomography (CT) & 20 & 21 & \\
\hline Ultrasound & 4 & 8 & \\
\hline No pre-op imaging & 13 & & \\
\hline
\end{tabular}


In terms of management, there were a range of operations performed which were categorised into laparoscopic appendicectomy, laparoscopic bowel resection, laparoscopic washout, open appendicectomy, open bowel resection or others. In the ADD group, twentynine patients underwent a laparoscopic appendicectomy $(78 \%)$, three underwent laparoscopic bowel resection (8\%), one patient had a laparoscopic washout (2.7\%), two patients had an open appendicectomy (5\%), two patients had open bowel resection (5\%) and one patient was categorized as 'other' (2.7\%). In the AA group, thirty-eight patients underwent a laparoscopic appendicectomy (95\%), one had a laparoscopic washout (2.5\%) and one patient had an open appendicectomy $(2.5 \%)$. This difference in the operative management was statistically significant $(p<0.05)$. The operative details are summarised in Table 2.
The use of intra-venous antibiotics was comparable between groups $(75 \%$ in ADD group vs $80 \%$ in AA group). Patient hospital length of stay was also comparable at mean 4.7 in ADD group (range 2-28) vs 3.7 in AA group (range $2-9 ; p>0.05$ )

The pathology records were then further examined. In the ADD group there were sixteen patients with acute uncomplicated appendicitis $(43.2 \%)$, eleven with perforation (29.7\%), four with uninflamed appendix (10.8\%) and three with an appendiceal mass (8.1\%). This is in comparison to the AA group consisting of thirty uncomplicated appendicitis $(75 \%)$ and ten perforated appendixes (25\%). On comparing the groups, the risk of a complicated appendicitis with either mass or perforation was significantly higher in the ADD group $(p<0.05)$. The subtype of appendiceal diverticula was also recorded with Type 1 (a normal appendix and acutely inflamed diverticulum) occurring

Table 2. Operative details

\begin{tabular}{lccc}
\hline & $\begin{array}{c}\text { Appendiceal Diverticular } \\
\text { Disease (ADD) }\end{array}$ & $\begin{array}{c}\text { Acute Appendicitis control group } \\
\text { (AA) }\end{array}$ & p value \\
\hline Operation Type & $29(78 \%)$ & $38(95 \%)$ & $p<0.05$ \\
\hline Laparoscopic appendix & $3(8 \%)$ & $1(2.5 \%)$ & \\
\hline Laparoscopic bowel resection & $1(2 \%)$ & $1(2.5 \%)$ & \\
\hline Laparoscopic washout & $2(5 \%)$ & & \\
\hline Open appendix & $2(5 \%)$ & & \\
\hline Open bowel resection & $1(2 \%)$ & $30(75 \%)$ & \\
\hline Other & & $19(25 \%)$ & \\
\hline Operative Findings & $15(43 \%)$ & & \\
\hline Uncomplicated appendicitis & $11(29 \%)$ & & \\
\hline Perforated appendix & $3(8 \%)$ & & \\
\hline Appendiceal mass & $4(11 \%)$ & & \\
\hline Non-inflamed appendix & & & \\
\hline
\end{tabular}

Table 3. Follow up

\begin{tabular}{lccc}
\hline & $\begin{array}{c}\text { Appendiceal Diverticular } \\
\text { Disease (ADD) }\end{array}$ & $\begin{array}{c}\text { Acute Appendicitis control group } \\
\text { (AA) }\end{array}$ & p value \\
\hline Colonoscopy & $15(40.5 \%)$ & $4(10 \%)$ & \\
\hline Colonic Diverticular disease & & & \\
\hline Total & $13(35.1)$ & $1(2.5)$ & $\mathrm{p}<0.01$ \\
\hline Diagnosis on imaging & 4 & 0 & \\
\hline Diagnosis on colonoscopy & 9 & 1 & $\mathrm{p}<0.001$ \\
\hline Colonic polyp & $7(19 \%)$ & $1(2.5 \%)$ & $\mathrm{p}<0.01$ \\
\hline Malignancy & $7(19 \%)$ & &
\end{tabular}


Table 4. Classification of appendiceal diverticular disease

\begin{tabular}{lc}
\hline Histopathology findings & No. of cases \\
\hline Site of diverticula & 23 \\
Tip & 3 \\
Middle & 0 \\
Base & 2 \\
Along length of appendix & 9 \\
Not specified & \\
\hline Diverticuli found on & 25 \\
Macroscopic examination & 12 \\
Microscopic examination & \\
\hline
\end{tabular}

in eight cases (21.6\%), type 2 (an acutely inflamed diverticulum with appendicitis) in thirteen cases $(35.1 \%)$, type 3 (conventional appendicitis with uninflamed diverticula) in nine cases $(24.3 \%)$ and type 4 (an incidental diverticulum without appendicitis) in seven cases (18.9\%). An interesting observation made from the pathology was that the appendiceal diverticuli were predominantly found at the tip of the appendix, frequently on further sections (Table $d$ ).

The presence of concomitant colonic diverticula was found in thirteen patients with ADD (35.1\%) compared to only one patient in the AA group (2.5\%) $(\mathrm{p}<0.01)$.

Follow up colonoscopy was performed in fifteen patients $(40.5 \%)$ in the ADD group but only four patients $(10 \%)$ of the AA group. In the ADD group, findings included seven patients with polyps (18.9\% of total ADD group) compared to only one polyp in the AA group (2.5\% total AA group). This was statistically significant $(\mathrm{p}<0.001)$.

The rate of abdominal malignancy was also investigated in both groups. In the ADD group, a total of 7 patients with malignancy were identified (18.9\%) comprising of 3 appendiceal mucinous neoplasm, 3 colonic neoplasm and 1 ovarian-related neoplasm. This is in comparison to only 1 patient $(2.5 \%)$ in the AA group who was found to have an ovarian malignancy. This difference was also statistically significant $(\mathrm{p}<0.01)$. Follow-up results are summarised in Table 3.

\section{Discussion}

Acute appendicitis is a common cause of acute right iliac fossa pain. However, other differentials that could cause similar signs and symptoms should be considered, such as the possibility of appendiceal diverticular disease. The difficulty with diagnosing ADD stems from its similar presentation to AA and indeed it is mostly a post-operative histological diagnosis. As such ADD is also often overlooked and erroneously thought to be a variant of AA with minimal clinical implications. The aim of this paper is to increase clinician awareness about ADD, as well as the potential complications that could arise, in particular the potential association with lower GI malignancy.

Lipton et al classified ADD into four major morphological subtypes (Table 5) (9). Type 1 being diverticulitis with a normal appendix, Type 2 involves diverticulitis with appendicitis, Type 3 represents the presence of a noninflamed diverticulum with associated appendicitis, and finally Type 4 is a non-inflamed diverticulum with a normal appendix $(10,11)$. We applied this classification system to our study and observed that the majority of cases were of the second subtype. This is in contrast to the literature that quotes Type 1 to be the commonest of the four major morphological subtypes (12).

The pathophysiology of the formation of ADD is poorly understood. There are several theories that have been hypothesized to explain the mechanisms forming acquired ADD and are broadly classified into inflammatory vs. non-inflammatory (12). Cases of ADD caused by inflammation result in a narrower lumen, followed by weakening and thinning of the intestinal wall, and sub-

Table 5. Classification of appendiceal diverticular disease.

\begin{tabular}{ll}
\hline Type 1 & Acute diverticulitis with a normal appendix \\
\hline Type 2 & Acute diverticulitis with acute appendicitis \\
\hline Type 3 & $\begin{array}{l}\text { Non-inflamed diverticulum with associated acute } \\
\text { appendicitis }\end{array}$ \\
\hline Type 4 & Non-inflamed diverticulum with a normal appendix \\
\hline
\end{tabular}


sequently, an increased risk of mucosal herniation or formation of appendiceal diverticulum $(12,13,14)$. In non-inflammatory causes, the formation of ADD often followed the effect of increased intra-luminal pressure secondary to multiple factors including intra-luminal obstruction by fecaliths, polyps, or previous inflammation $(12,14)$. Another significant non-inflammatory cause of ADD to consider is in cystic fibrosis patients where there are an increased number of goblet cells and secretions in the vermiform appendix $(12,15,16)$. George DH reported that the incidence of appendiceal diverticulosis was found to be $14 \%$ in patients with cystic fibrosis as opposed to the incidence of this condition in the general population that has been quoted to be between $0.004-2.1 \%$ of appendicectomy histology sections (17).

Patients who have underlying appendiceal diverticula are typically asymptomatic or have a more indolent course. In 2013, Sohn et al. compared the clinical characteristics of patients who were diagnosed with AA to those diagnosed with appendiceal diverticulitis (16). ADD has previously been reported to occur in older patients, typically in the fourth to fifth decade of life. Their results demonstrated that patients with ADD were typically of the older age group, with the mean age of $49.0 \pm 15.2$ as opposed to $25.4 \pm 14.2$ in the appendicitis group (16). Our study yielded results consistent with the literature, with the average age of patients with appendiceal diverticulitis being 50.1 in contrast to an average age of 37.3 in the acute appendicitis group $(\mathrm{p}<0.01)$, thus making this an important risk factor to consider. Some literature described the male gender to be a risk factor, however we did not demonstrate a statistically significant difference with the diagnosis of ADD in males versus females, and this was similar to Sohn et al.'s findings $(3,12,16,18,19)$.

As discussed, the pre-operative diagnosis of ADD is difficult however there are certain investigations that could indicate a greater likelihood of ADD as opposed to AA. In terms of biochemical markers, we found that the
WCC of patients with ADD was significantly lower with the average value of $11.1 \times 10^{9} / \mathrm{L}$ compared with AA who had an average WCC of $13.3 \times 10^{9} / \mathrm{L}(\mathrm{p}<0.01)$. The $\mathrm{CRP}$ value in ADD patients was also higher than those with AA. Albeit not statistically significant in our patient cohort, a higher CRP value along with the lower WCC in ADD patients has been shown to be significant in current literature, potentially indicating that patients with appendiceal diverticulitis have had a longer duration of underlying inflammation than patients with $\mathrm{AA}(20,21)$.

Imaging modalities such as USS and CT utilized for further investigations in patients with right lower quadrant abdominal pain are not specifically targeted to identify ADD as it remains a pathological diagnosis at this stage. The first documented suspicion of appendiceal diverticular found on CT was in 2004 (18). Yardimci et al.'s retrospective study of CT findings of 24 acute appendiceal diverticulitis cases reported that the presence of periappendiceal fat stranding, a larger appendiceal diameter $(12.5 \pm 2.0 \mathrm{~mm}$ vs. $10.4 \pm 2.9 \mathrm{~mm}$ in the non-appendiceal diverticulitis group) (Fig. 1), as well as the presence of periappendiceal loculated fluid were statistically significant features of appendiceal diverticulitis

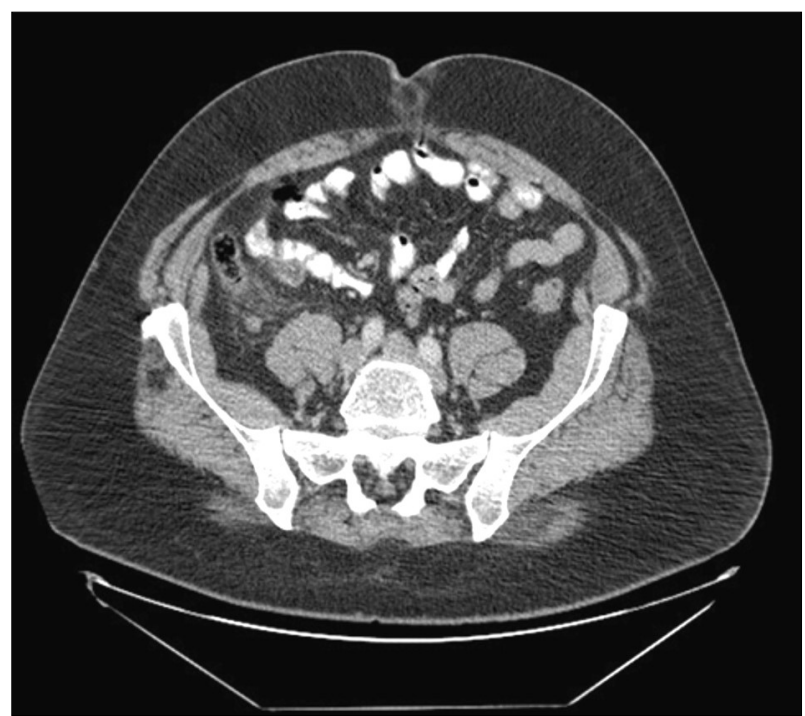

Figure 1. Axial slice of CT abdomen demonstrating appendicitis with a diameter of $20 \mathrm{~mm}$ with surrounding inflammatory stranding. 
(22). Patil AY's case report states that the diagnosis of appendiceal diverticulitis can be suspected if $\geq 1$ microabscesses were present on $\mathrm{CT}$, with the additional features of an enhancing rim accompanied by a heterogenous hypodense centre, as well as localized fat stranding (23). A recent article published in the Japanese Journal of Radiology that studied CT findings of a total of 388 patients with AA and ADD between 2009 and 2014 identified that a potential indicator of $\mathrm{ADD}$ was peri-appendiceal or peri-caecal fluid collection (24). Interestingly, Osada et al. stated that multi-detector CT (MDCT) had the potential of diagnosing appendiceal diverticulitis in up to $86 \%$ of cases that were confirmed on histopathological sections (25). In terms of sonographic findings, a more prominently thickened appendiceal wall, the presence of air in the appendix as well as pouch-like projections thought to be meosappendiceal inflammatory changes were thought to distinguish ADD from AA in a case report by Kubota et al (26).

There are several clinical implications known to arise from ADD that should be emphasized, in particular appendiceal perforation and malignancy. Previous authors have indicated that the risk of perforation of the appendix in patients with ADD is up to four times more likely than in patients with AA, increasing the mortality rate by 30 -fold $(3,9,14,27)$. In our study, the presence of perforated appendix and incidental intra-operative finding of an appendiceal mass were greater in the appendiceal diverticula group as opposed to the AA group $(p<0.05)$.

In regard to malignancies, $\mathrm{Ng}$ et al.'s report described a case of primary appendiceal adenocarcinoma presenting with a perforated appendiceal diverticulitis (28). Kallenbach et al.'s study of appendix specimens found $43.6 \%$ of the 39 appendiceal diverticula specimens had an underlying appendiceal neoplasm, and Chan et al.'s Australian study reported that patients who had ADD were up to ten times more likely to have an underlying appendiceal neoplasm $(29,30)$. In our data the incidence of malignancy in our ADD group was shown to be in $18.9 \%$ of the 37 appendicectomy specimens, statistically higher than in the AA group which had an incidence of $2.5 \%$ $(p<0.01)$. Our data showed not only appendiceal neoplasms but also colonic neoplasm and ovarian neoplasm. Dupre et al.'s study found $48 \%$ of the 23 appendicectomy specimens that had features of diverticulosis had an appendiceal malignancy and stressed the lack of emphasis in surgical pathological textbooks or teachings, thus exemplifying the need for thorough histopathological examinations of appendicectomy specimens to prevent overlooking or missing this diagnosis (31).

A post-operative colonoscopy was performed in 15 patients $(40.5 \%)$ in the ADD group but only in 4 patients $(10 \%)$ of the AA group. $18.9 \%$ of patients in the ADD group had colonic polyps on colonoscopy as compared to $2.5 \%$ of the AA group $(\mathrm{p}<0.001)$. At present, there are no studies suggesting an association between ADD and colonic polyps, making our study the first to observe this association. More research with a larger patient cohort is required to further investigate the significance of the relationship between the two factors. In general, a colonoscopy following an appendicectomy is still recommended in patients above the age of 50 to rule out underlying diverticular disease or neoplasms. Dhadlie and Mehanna's study of screening colonoscopies in post-appendicectomy patients above the age of 50 demonstrated that $46 \%$ of the 43 patients included in the retrospective study had pertinent findings on colonoscopy such as malignancies, suggesting that there was still a role for post-appendicectomy screening colonoscopies in this age cohort (32).

The definitive management of symptomatic $\mathrm{ADD}$ and $\mathrm{AA}$ is an appendicectomy. Our results showed a difference in the operative management between the two groups with cases of ADD proceeding to more major procedures such as laparoscopic bowel resection (8\%), laparoscopic washout $(2.7 \%)$, laparoscopic converting to open appendicectomy (5\%) and open bowel resection $(5 \%) \quad(p<0.05)$. These more complex cases can be related to longer patient recovery and greater risks of complications in ADD. 
Controversy still exists in regard to the management of incidental asymptomatic ADD, however with the risk of progression ADD into diverticulitis in two thirds of cases, the aforementioned greater risk of perforation and appendiceal neoplasms, it has been recommended that an elective appendicectomy be performed (16, 33).

\section{Conclusion}

Due to the similarities in the clinical presentation of $\mathrm{ADD}$ and $\mathrm{AA}$, a pre-operative or intra-operative diagnosis of $\mathrm{ADD}$ remains a challenge. Older patients presenting with symptoms of appendicitis should be given a higher index of suspicion for ADD. As ADD is associated with greater rates of appendiceal perforation and is a statistically significant risk of polyps and malignancy as demonstrated in our study, we recommend that patients who have a histological diagnosis of ADD be advised to have a colonoscopy performed following the acute post-operative phase as a precautionary measure to rule out underlying malignancy.

\section{Acknowledgements}

We would like to thank the Sir Charles Gairdner Hospital Pathology Department for assisting in providing histological data.

\section{Conflicts of Interests and Source of Funding}

None.

\section{References}

1. Kelynack TN. A Contribution to the Pathology of the Vermiform Appendix. London: HK Lewis; 1893, p. 60-61.

2. Yates LN. Diverticulum of the Vermiform Appendix. The Western Journal of Medicine. 1972;116:9-11

3. Phillips BJ, Perry CW. Appendiceal Diverticulitis. Mayo Clinic Proceedings. 1999;74(9):890-892.

4. Favara BE. Multiple Congenital Diverticula of the Vermiform Appendix. 1968;49(1):60-64.

5. Hamed Kabiri, Leon E Clarke, Chris D Tzarnas. Appendiceal Diverticulitis. Am Surg. 2006;72(3):221-3.

6. $\mathrm{Ng} \mathrm{JL}$, Wong SL, Matthew R. Appendiceal diverticulosis: a harbinger of underlying primary appendiceal carcinoma? Journal of Gastrointestinal Oncology. 2018;9(2):E1-E5.
7. Terada T. Appendiceal Diverticulitis Clinically Masquerading as an Appendiceal Carcinoma. Case Rep Gastrointest Med. 2014; 2014:837860.

8. Dupre MP, Jadavji I, Matshes E, Urbanski SJ. Diverticular disease of the vermiform appendix: a diagnostic clue to underlying appendiceal neoplasms. Human Pathology. 2008;39:1823-1826.

9. Lipton S, Estrin J, Glasser I. Diverticular Disease of the Appendix. Surg Gynecol Obstet. 1989;168(1):13-6.

10. Deng YW, Yang HB, Feng KC, Lei TH, Lee CP. Appendiceal diverticular disease. Formosan Journal of Surgery. 2013;46(1):4-9.

11. Heffernan DS, Saqib N, Terry M. A case of appendiceal diverticulitis, and a review of the literature. Irish Journal of Medical Science. 2009;178(4):519-21.

12. AbdullGaffar B. Diverticulosis and Diverticulitis of the Appendix. International Journal of Surgical Pathology. 2009;17(3):231-237.

13. Käser SA, Willi N, Maurer CA. Prevalence and clinical implications of diverticulosis of the vermiform appendix. 2013;41(4);13501356.

14. Majeski J. Diverticulum of the vermiform appendix is associated with chronic abdominal pain. The American Journal of Surgery. 2003;186(2):129-131.

15. McCarthy VP, Mischler EH, Hubbard VS, Chernick MS, Di Sant'agnese PA. Appendiceal abscess in cystic fibrosis. A diagnostic challenge. Gastroenterology. 1984;86(3):564-568.

16. Sohn TJ, Chang YS, Kang JH, Kim DH, Lee TS, Han JK, Kim HS, Hong YO. Clinical characteristics of acute appendiceal diverticulitis. Journal of the Korean Surgical Society. 2013;84(1):33-37.

17. George DH. Diverticulosis of the Vermiform Appendix in Patients with Cystic Fibrosis. Human Pathology. 1987;18(1):75-79.

18. Friedlich M, Malik N, Lecompte M, Ayroud Y. Diverticulitis of the appendix. Canadian Journal of Surgery. 2004;47(2):146-147.

19. Lobo-Machín I, Delgado-Plasencia L, Hernández-González I, BritoGarcía A, Burillo-Putze G, Bravo-Gutiérrez A et al. Appendiceal diverticulitis and acute appendicitis: differences and similarities. Rev Esp Enferm Dig. 2014;106(7):452-458.

20. Yamana I, Kawamoto S, Inada K, Nagao S, Yoshida T, Yamashita Y. Clinical characteristics of 12 cases of appendiceal diverticulitis: a comparison with 378 cases of acute appendicitis. Surg Today. 2012;42(4):363-367.

21. Ito D, Miki K, Seiichiro S, Hata S, Kobayashi K, Teruya M, Kaminishi M. Clinical and computed tomography findings of appendiceal diverticulitis vs acute appendicitis. World Journal of Gastroenterology. 2015;21(13):3921-3927.

22. Yardimci AH, Bektas CT, Pasaoglu E, et al. Retrospective study of 24 cases of acute appendiceal diverticulitis: CT findings and pathological correlations. Japanese Journal of Radiology. 2017;35(5): 225-232.

23. Patil AY, Levine MS, Grujic E, Goren RA. Clinical and CT findings in appendiceal diverticulitis. Clinical Imaging. 2014;38(3):350-352.

24. Fukata K, Takamizawa J, Miyake H, Nagai H, Yoshioka Y, Yuasa N, et al. Diagnosis of appendiceal diverticulitis by multidetector computed tomography (published online ahead of print, $2020 \mathrm{Mar}$ 14). Jpn J Radiol 2020;10.1007/s11604-020-00950-4. doi: https://doi.org/10.1007/s11604-020-00950-4

25. Osada H, Ohno H, Saiga K, Watanabe W, Okada T, Honda N. Appendiceal diverticulitis: multidetector CT features. Jpn J Radiol. 2012;30(3):242-8. Epub 2011 Dec 22

26. Kubota T, Omori T, Yamamoto J, Nagai M, Tamaki S, Sasaki K. Sonographic findings of acute appendiceal diverticulitis. World Journal of Gastroenterology. 2006;12(25):4104-4105.

27. Zubieta-O'Farrill G, Guerra-Mora JR, Gudiño-Chávez A, GonzalezAlvarado C, Cornejo-López GB, Villanueva-Sáenz E. Appendiceal diverticulum associated with chronic appendicitis. International Journal of Surgical Case Reports. 2014;5(12):961-963. 
28. Ng JL, Wong SL, Mathew R. Appendiceal diverticulosis: a harbinger of underlying primary appendiceal adenocarcinoma? Journal of Gastrointestinal Oncology. 2018;9(2):E1-E5.

29. Kallenbach K, Hjorth SV, Engel U, Schlesinger NH, Holck Susanne. Significance of acquired diverticular disease of the vermiform appendix: a marker of regional neoplasms? Journal of Clinical Pathology. 2012;65(7):638-642.

30. Chan DL, Lim C, Bakhtiar A, Khoury M, Smigelski M, Yeh D, Ravindran P. Clinical significance of appendiceal diverticulum: a significant marker of appendiceal neoplasia in Australian patients. International Journal of Colorectal Disease. 2018;33(11):
1569-1574.

31. Dupre MP, Jadavji I, Matshes E, Urbanski SJ. Diverticular disease of the vermiform appendix: a diagnostic clue to underlying appendiceal neoplasm. Human Pathology. 2008;39(12): 1823-1826.

32. Dhadlie S, Mehanna D. Rates of colorectal cancer detection in screening colonoscopy post appendicectomy in patients 50 years and over. Annals of Medicine and Surgery. 2018;36:239-241.

33. Fitzer PM, Rao KG, Bundrick TJ. Diverticulosis of the Appendix: Radiographic and Clinical Features. Southern Medical Journal. 1985;78(12):1512-1514. 